\title{
UPPSALA NATURAL RADIOCARBON MEASUREMENTS II
}

\section{INGRID OLSSON}

Uppsala Universitets Fysiska Institution

Uppsala, Sweden

The following list covers the samples measured at the Uppsala radiocarbon laboratory during 1959.

The technique used was described previously by the author (1958). The pretreatment will be described here briefly. Foreign material, e. g. rootlets, is removed before the chemical treatment is started. Wood, charcoal, peat, mud, and gyttja are washed with $\mathrm{HCl}$ and $\mathrm{NaOH}$. The alkali-soluble fraction is precipitated with $\mathrm{HCl}$ and (as a rule) $\mathrm{CaCl}_{2}$ and is sometimes washed, dried, and used as a humus fraction for comparison with the washed peat sample. Shells are washed with acid so that the outer parts will be removed. To check that the inner part is free from contamination, we interrupt the washing and use the $\mathrm{CO}_{2}$ from an intermediate layer for a $\mathrm{C}^{14}$ determination, which is compared with the determination from the innermost part. The proportional volume of each fraction is estimated gravimetrically or by manometric measurement of the $\mathrm{CO}_{2}$. If two or more layers agree, the dates can be used. When comparing different layers one must remember that the given errors correspond to $1 \sigma$. The dating of raised beaches and difficulties in using shell samples are discussed elsewhere by Blake (1959) and Olsson and Blake (in preparation). Most of the high-level shell samples from Spitsbergen, with finite ages higher than 30,000 years, are probably only minimum ages. The bones are treated in the same manner as previously described (Olsson, 1959).

The reference sample still consists of tree rings from A.D. 1785 to 1795 . The tree grew at Vårdsätra $\left(59^{\circ} 47.5^{\prime} \mathrm{N}\right.$ Lat, $17^{\circ} 37^{\prime} \mathrm{E}$ Long), Uppsala, Sweden. The cellulose is used.

All samples are compared, in respect to $\mathrm{C}^{14}$ activity, to the cellulose from the above-mentioned elm, but the ages of all samples are also corrected for isotopic fractionation as described previously (Olsson, 1959). Here a diagram (fig. 1) is included for all samples which have been examined for the deviation $\delta \mathrm{C}^{13}$ of the ratio $\mathrm{C}^{13} / \mathrm{C}^{12}$ from the Uppsala standard. The error in the $\mathrm{C}^{13} / \mathrm{C}^{12}$ ratio is $\pm 1 \%$.

The value 5570 years has been used for the half-life of $\mathrm{C}^{14}$.

The results given are expressed in years B.P. The errors include the standard deviations $(\sigma)$ of the counted particles for the unknown sample, the reference sample, and the background sample as well as the error in the $\delta \mathrm{C}^{13}$ values. When the activity is very low, so that $2 \sigma$ corresponds to a possibility of infinite age, $2 \sigma$ has been used instead of $\sigma$.

A few samples had to be diluted with $\mathrm{CO}_{2}$ from an old source to bring them to the normal working pressure of 3 atmospheres.

\section{ACKNOWLEDGMENTS}

The descriptions of the samples are based on information provided by those responsible for collecting and submitting them. Before the final manu- 
script was ready most contributors were kind enough to read the draft and suggest improvements, and sincere thanks are due to them.

The author expresses gratitude to Fil. mag. Sigvard Olsson and Fil. stud. Per Lindhagen, who have helped her with the age determinations. Special SAMPLE

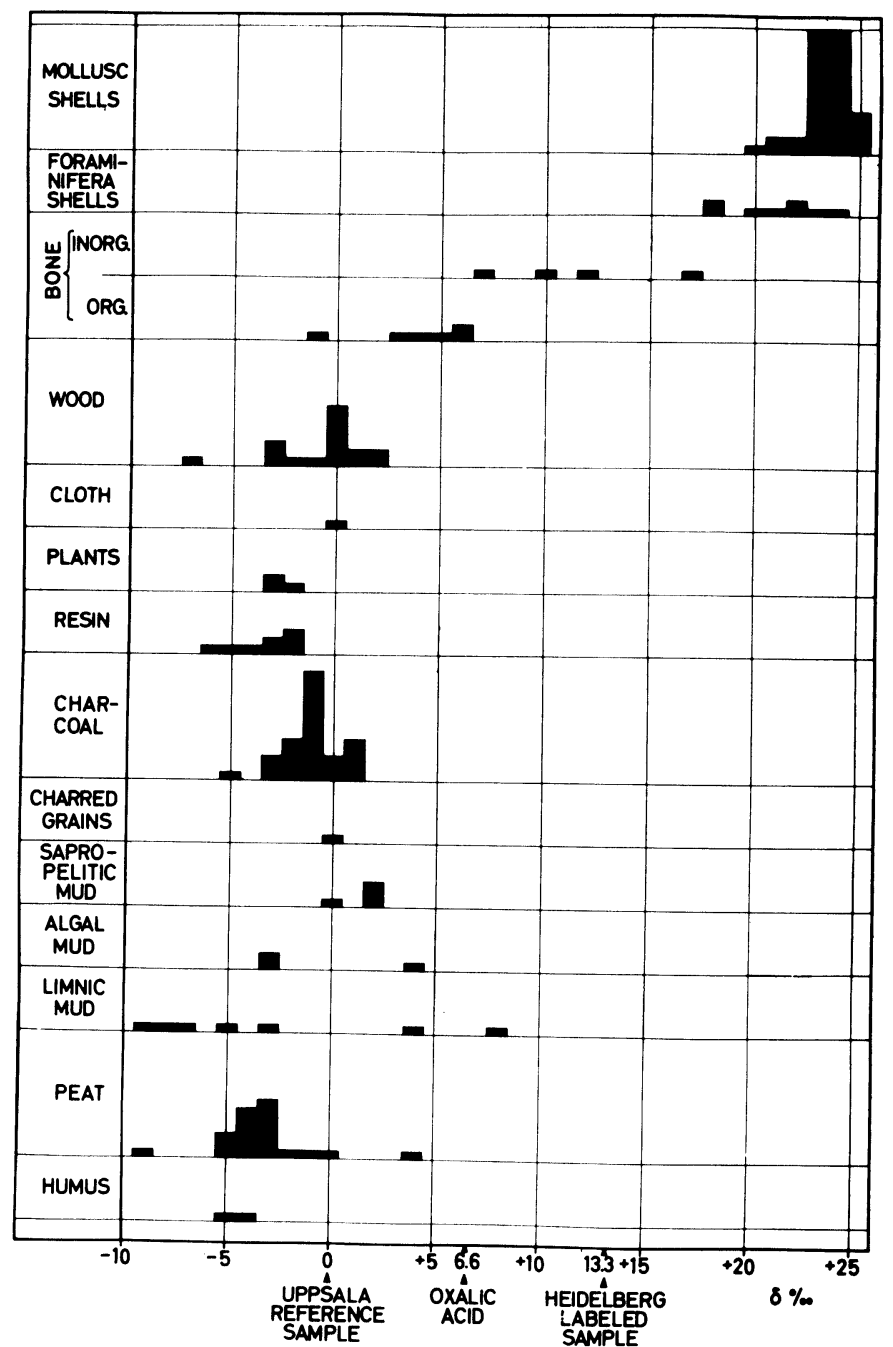

Fig. 1. The deviation of the ratio $\mathrm{C}^{13} / \mathrm{C}^{12}$ from the Uppsala reference sample, (elm wood, A.D. 1785-1795).

The deviation is denoted by $\delta \mathrm{C}^{13}$ and is expressed in per mil:

$$
\delta \mathrm{C}^{13}=\frac{\mathrm{R}_{\mathrm{x}}-\mathrm{R}_{\mathrm{u}}}{\mathrm{R}_{\mathrm{u}}} \times 1000
$$

where $R_{x}$ and $R_{u}$ are the ratios $C^{13} / C^{12}$ for the sample and the reference sample respectively. The correction in the net counting rate of $\mathrm{C}^{14}$ is $-2 \delta . A 1 \%$ increase in the net counting rate corresponds to a decrease of 8 years in the age. 
thanks are due also to Ingenjör R. Ryhage and Fröken Gunilla Norman, Karolinska Institutet, Stockholm, for making the $\mathrm{C}^{13} / \mathrm{C}^{12}$ determinations, to Prof. K. Siegbahn, who has made it possible to do this work at the institute, and to Statens Naturvetenskapliga Forskningsråd, which has given the laboratory financial support.

\section{SAMPLE DESCRIPTIONS \\ I. GEOLOGIC SAMPLES \\ A. Mediterranean Area}

\section{U-90. Levant 190, 227 to $231 \mathrm{~cm}$}

Sapropelitic mud from core 190 ( $33^{\circ} 54^{\prime}$ N Lat, $26^{\circ} 10^{\prime} \mathrm{E}$ Long), depth 227 to $231 \mathrm{~cm}$; total length of core $938 \mathrm{~cm}$; depth in the sea $2900 \mathrm{~m}$; slightly irregular bottom with westward slope. Coll. 1948 by the Swedish Albatross Expedition (Petterson) ; subm. by Eric Olausson, Uppsala Universitets Mineralogisk-Geologiska Institution. Comment: $2 \sigma$ is used. $\delta \mathrm{C}^{13}=+1.8 \%$. A few other dates from the Levant were reported by Olsson (1959).

\section{Western Mediterranean Sea series}

Shells of Foraminifera from deep-sea cores. Coll. 1948 by the Swedish Albatross Expedition (Pettersson); subm. by K. Gösta Eriksson, Uppsala Universitets Kvartärgeologiska Institution. Comment: samples did not contain enough coarse fraction $(>74 \mu)$ for separate measurement as suggested by Rubin and Suess (1955) and Ericson and others (1956). The risk of errors from exchange and from recrystallization must also be considered.

U-140. Core 21001,21 to $25 \mathrm{~cm}$

$6450 \pm 190$

Core $21001\left(37^{\circ} 26^{\prime} \mathrm{N}\right.$ Lat, $1^{\circ} 5^{\prime} \mathrm{E}$ Long), depth 21 to $25 \mathrm{~cm}$; depth in the sea $2783 \mathrm{~m}$. Comment: coarse fraction $(>62 \mu)$, diluted. $\delta \mathrm{C}^{13}=$ $+22.3 \%$.

U-141. Core 21002, 62 to $65 \mathrm{~cm} \quad 5460 \pm 220$

Core $21002\left(37^{\circ} 26^{\prime} \mathrm{N}\right.$ Lat, $1^{\circ} 5^{\prime} \mathrm{E}$ Long $)$, depth 62 to $65 \mathrm{~cm}$. The level corresponds to a maximum of Globigerinoides rubra. Comment: coarse fraction, diluted. $\delta \mathrm{C}^{13}=+18.3 \%$.

U-143. Core $21102,62.5$ to $65 \mathrm{~cm}$

$\mathbf{5 9 5 0} \pm \mathbf{2 1 0}$

Core $21102\left(35^{\circ} 55^{\prime} \mathrm{N}\right.$ Lat, $2^{\circ} 20^{\prime} \mathrm{W}$ Long), depth 62.5 to $65 \mathrm{~cm}$; depth in the sea $1325 \mathrm{~m}$. This level corresponds to a rise in the content of sand. Comment: a fraction $>4 \mu$ was used, diluted. $\delta \mathrm{C}^{13}=+18.6 \%$, but this value is uncertain as it was measured after the dilution.

U-142. Core 21104, 223 to $227.5 \mathrm{~cm}$

$10,800 \pm 400$

Core 21104 $\left(35^{\circ} 55^{\prime} \mathrm{N}\right.$ Lat, $2^{\circ} 20^{\prime} \mathrm{W}$ Long), depth 223 to $227.5 \mathrm{~cm}$; depth in the sea $1325 \mathrm{~m}$. This level corresponds to an increase of Globigerirubra and a decrease of Globegerina pachyderna. Comment: a fraction $4 \mu$ was used. $\delta \mathrm{C}^{13}=+20.6 \%$.

U-158. Core 21106, 354.5 to $359.5 \mathrm{~cm} \quad 18,200 \pm 350$

Core $21106\left(35^{\circ} 55^{\prime} \mathrm{N}\right.$ Lat, $2^{\circ} 20^{\prime} \mathrm{W}$ Long), depth 354.5 to $359.5 \mathrm{~cm}$; depth in the sea $1325 \mathrm{~m}$. This level corresponds to a minimum of Globorotalia scitula and Globegerina pachyderna and a rise of Globigerinoides rubra. Comment: a fraction $>4 \mu$ was used, diluted. $\delta \mathrm{C}^{13}=+21.2 \%$. 
Core $20905\left(38^{\circ} 31^{\prime} \mathrm{N}\right.$ Lat, $3^{\circ} 50^{\prime}$ E Long), depth 322.5 to $327.5 \mathrm{~cm}$; depth in the sea $2596 \mathrm{~m}$. This level corresponds to a rise of Globigerinoides rubra and a decrease of Globegerina pachyderna. Comment: a fraction $>4 \mu$ was used. $\delta \mathrm{C}^{13}=+20.6 \%$.

$$
\text { B. Iceland }
$$

$4970 \pm 100$

\section{U-77. Skeidararsandur}

Peat, Parvocaricetum, from Skeidararsandur $\left(64^{\circ} 3^{\prime} \mathrm{N}\right.$ Lat, $17^{\circ} 4^{\prime} \mathrm{W}$

Long), Iceland, transported by the glacier Skeidararjökull. The peat contains freshwater diatoms and plant pollen together with pollen of Betula. Coll. 1951 and subm. by Jón Jónsson, Uppsala Universitets Paleontologiska Institution. $\delta \mathrm{C}^{13}=-4.1 \%$.

\section{Vestspitsbergen series}

\section{Spitsbergen}

Shells from various altitudes. Samples were measured to determine the rate of land rise. All altitudes are above mean sealevel. Shorelines have been found up to $96 \mathrm{~m}$ and marine shells up to $84.5 \mathrm{~m}$. Coll. by R. W. FeylingHanssen, Norges Geologiske Undersøkelse, Oslo, Norway; subm. by Anders Rapp, Uppsala Universitets Geografiska Institution.

\section{U-133. Woodf jorden}

$$
400 \pm 60
$$

Astarte borealis from Tangen $\left(79^{\circ} 30^{\prime} \mathrm{N}\right.$ Lat, $14^{\circ} \mathrm{E}$ Long), Mushamna, Spitsbergen; recent beach; 0 to $0.5 \mathrm{~m}$ altitude. Coll. 1952. Comment: inner $60 \%$ was used. $\delta \mathrm{C}^{13}=+22.0 \%$.

\section{U-126. Mytilusbekken 343b}

$3810 \pm 90$

Mytilus edulis from Mytilusbekken ( $78^{\circ} 28^{\prime} \mathrm{N}$ Lat, $16^{\circ} 23^{\prime} \mathrm{E}$ Long), Billefjorden, Spitsbergen; $5.8 \mathrm{~m}$ altitude. Coll. 1950. Comment: inner $55 \%$ of the shells was used. $\delta \mathrm{C}^{13}=+24.2 \%$.

\section{U-125. Mytilusbekken 343a}

$3985 \pm 150$

Shell layer surrounding the part used for sample U-126. Comment: diluted. The layer corresponds to $30 \%$ of the shells; $15 \%$ was removed by washing. $\delta \mathrm{C}^{13}=+22.5 \%$.

\section{U-130. Ekholmvika 350b}

$7595 \pm-110$

Astarte borealis from Ekholmvika $\left(78^{\circ} 35^{\prime} \mathrm{N}\right.$ Lat, $16^{\circ} 37^{\prime} \mathrm{E}$ Long), Billefjorden, Spitsbergen; $17 \mathrm{~m}$ altitude. Coll. 1950. Comment: inner $55 \%$ of the shells was used. $\delta \mathrm{C}^{13}=+24.1 \%$.

\section{U-129. Ekholmvika 350a}

Shell layer surrounding the part used for sample U-130. Comment: the layer corresponds to $35 \%$ of the shells; $10 \%$ was removed by washing. $\delta \mathrm{C}^{13}=$ $+24.5 \%$.

\section{U-124. Myadalen 326b}

Mya truncata or Saxicava arctica from Myadalen $\left(78^{\circ} 33^{\prime} \mathrm{N}\right.$ Lat, $16^{\circ} 4^{\prime}$ E Long), Billefjorden, Spitsbergen; $42 \mathrm{~m}$ altitude. Coll. 1950. Comment: diluted. Inner $20 \%$ of the shells was used. $\delta \mathrm{C}^{13}=+23.0 \%$. 
U-123. Myadalen 326a

$9580 \pm 170$

Shell layer surrounding the part used for sample U-124. Comment: the layer corresponds to $50 \%$ of the shells; $30 \%$ was removed by washing. $\delta \mathrm{C}^{13}$ $=+24.8 \%$.

U-128. Phantomvika 349b

$9980 \pm 140$

Mya truncata from N of Phantomvika ( $78^{\circ} 33^{\prime} \mathrm{N}$ Lat, $16^{\circ} 30^{\prime} \mathrm{E}$ Long), Billefjorden, Spitsbergen; $50.7 \mathrm{~m}$ altitude. Coll. 1950. Comment: inner $33 \%$ of the shells was used. $\delta \mathrm{C}^{13}=+24.4 \%$.

\section{U-127. Phantomvika 349a}

$9850 \pm 140$

Shell layer surrounding the part used for sample U-128. Comment: the layer corresponds to $53 \%$ of the shells; $14 \%$ was removed by washing. $8 \mathrm{C}^{13}=$ $+23.9 \%$.

U-132. Teltf jellbekken $358 \mathrm{~b}$

$9840 \pm 150$

Shells from Teltfjellbekken ( $78^{\circ} 38^{\prime} \mathrm{N}$ Lat, $16^{\circ} 44^{\prime} \mathrm{E}$ Long), Billefjorden, Spitsbergen; $56 \mathrm{~m}$ altitude. Coll. 1950. Comment: diluted. Inner $50 \%$ of the shells was used. $\delta \mathrm{C}^{13}=+24.5 \%$.

U-131. Teltfjellbekken 358 a

$10,460 \pm 330$

Shell layer surrounding the part used for sample U-132. Comment: diluted. The layer corresponds to $35 \%$ of the shells; $15 \%$ was removed by washing. $\delta \mathrm{C}^{13}=+23.4 \%$.

General Comment: the data indicate a rapid land uplift in Central Spitsbergen of the order of $2 \mathrm{~m}$ per century during the earliest part of postglacial time, from 10,000 to 8000 B.P., followed by a slow uplift which was less than onetenth of this. U-130 is the only sample determining the change from a rapid to a slow rate of land uplift. The figures for the rate are thus preliminary. The slow displacement, as well as the rapid one, will be investigated further. The Quaternary geology and the occurrence of shells are described by FeylingHanssen (1955). The stratigraphy is also discussed together with the radiocarbon dates in a review (Feyling-Hanssen and Olsson, in press). In Nordaustlandet, as compared with Vestspitsbergen, the uplift of the land about 9000 B.P. was more rapid, and the later one was slower. See Nordaustlandet series below.

\section{Nordaustlandet series}

Driftwood, shells, bone, peat, and mud found at various altitudes. These samples were mostly collected from raised beaches and constitute a continuation of the Nordaustlandet series collected for determination of land uplift (see Olsson, 1959). The raised beaches are usually developed on the underlying till. Seaborne pumice is also commonly found at the "Upper pumice level", as it has been called by Donner and West (1955). All altitudes are above mean sealevel. The marine limit is higher than $100 \mathrm{~m}$. Samples, except U-92, U-93, and U-166, coll. by Weston Blake, Jr., Ohio State University, Columbus, and Geografiska Institutet, Stockholms Högskola, Stockholm. All samples, except U-92 and U-93, subm. by Blake.

U-121. Lågфya 41

$\mathbf{5 4 0} \pm \mathbf{7 0}$

Astarte borealis from Diabasvika, Lågøya $\left(80^{\circ} 34^{\prime} \mathrm{N} \mathrm{Lat}, 18^{\circ} 35^{\prime} \mathrm{E}\right.$ 
Long), Spitsbergen; $1 \mathrm{~m}$ altitude; ca. $4 \mathrm{~m}$ from the sea. Coll. 1958. Comment: some of the three pairs of shells used were still joined and their periostracum was still left. Inner $80 \%$ of the shells was used. $\delta \mathrm{C}^{13}=+22.0 \%$.

U-122. Murchisonf jorden $42 \quad 295 \pm 70$

Buccinum glaciale from NE side of Nordre Russøya $\left(80^{\circ} 0^{\prime} \mathrm{N}\right.$ Lat, $18^{\circ}$ 9' E Long), Murchisonfjorden; Spitsbergen; $1.5 \mathrm{~m}$ altitude; $10 \mathrm{~m}$ from the sea. Sample from the ground amid the debris of the old Russian trapping hut (sample U.37). Coll. 1958. Comment: inner $87 \%$ of the shells was used. $\delta \mathrm{C}^{13}=+23.7 \%$.

U-85. Lady Franklinf jorden 32

$4970 \pm 110$

Shells from SW side of Lady Franklinfjorden $\left(80^{\circ} 6^{\prime} \mathrm{N}\right.$ Lat, $19^{\circ} 14^{\prime} \mathrm{E}$ Long), Spitsbergen; 1 to $2 \mathrm{~m}$ altitude; $3 \mathrm{~m}$ from the sea. Found in calcareous till at outer end of Søre Franklinbreen lateral moraine. Coll. 1958. Comment: sample includes old and young shells mixed when the glacier advanced. Inner $48 \%$ of the shells was used. $\delta \mathrm{C}^{13}=+21.0 \%$.

U-170. Murehisonf jorden 46b $>40,000$

Balanus, Astarte, and probably Saxicava from Krossøya $\left(79^{\circ} 57^{\prime}\right.$ N Lat, $18^{\circ} 2^{\prime} \mathrm{E}$ Long), Murchisonfjorden, Spitsbergen; 2.5 to $6 \mathrm{~m}$ altitude; $5 \mathrm{~m}$ from the sea. Sample exposed in a cliff and gathered in the basal part of a gray-green calcareous till overlying the red till which is found at most places along this coast. Coll. 1958. Comment: sample consisted of small thin frag. ments, some with the periostracum still preserved. Inner $40 \%$ of the shells was used. Diluted. $2 \sigma$ is used. $\delta \mathrm{C}^{13}=+23.6 \%$.

U-112. Lady Franklinf jorden 12

$6900 \pm 110$

Wood from Kapp Lady facing Lady Franklinfjorden $\left(80^{\circ} 12^{\prime} \mathrm{N}\right.$ Lat, $18^{\circ}$ $42^{\prime}$ E Long), Spitsbergen; $6.2 \mathrm{~m}$ altitude; $75 \mathrm{~m}$ from the sea. Sample from exposed part of a $\log$ partly buried in pebbles and sand of a raised beach. This level is the upper pumice level. Coll. 1958. $\delta \mathrm{C}^{13}=-0.9 \%$.

U-107. Murchisonf jorden 8

$6200 \pm 100$

Wood from $W$ side of Vestre Tvillingneset facing Ringertzøya, Murchisonfjorden $\left(80^{\circ} 3^{\prime} \mathrm{N}\right.$ Lat, $18^{\circ} 8^{\prime} \mathrm{E}$ Long $)$, Spitsbergen; $7.6 \mathrm{~m}$ altitude; $50 \mathrm{~m}$ from the sea. Sample from exposed part of a $\log$ partly buried in pebbles, sand, and dolomite fragments of a raised beach. This level is the upper pumice level. Coll. 1958. $\delta \mathrm{C}^{13}=+0.9 \%$.

U-109. Murchisonf jorden 8 A o I

$6220 \pm 110$

Organic fraction of whalebone from $\mathbb{W}$ side of Vestre Tvillingneset facing Ringertzøya, Murchisonfjorden $\left(80^{\circ} 3^{\prime} \mathrm{N}\right.$ Lat, $18^{\circ} 8^{\prime} \mathrm{E}$ Long), Spitsbergen; $7.5 \mathrm{~m}$ altitude; $50 \mathrm{~m}$ from the sea. The bone was partly buried in pebbles, sand, and dolomite fragments of a raised beach. This level is the upper pumice level. Coll. 1958. Comment: this fraction corresponds to the first portion of $\mathrm{CO}_{2}$ obtained by combustion. Since the inorganic fraction, U-108, gave a lower age and since the contaminations expected here should give lower ages, the organic fractions, U-109 and U-110, may also be affected by younger carbon. $\delta \mathrm{C}^{13}=+2.8 \%$.

U-110. Murchisonf jorden 8 A o II

$6380 \pm 150$

Organic fraction of the whalebone used for sample U-109 and U-108 ob- 
tained at the end of combustion. Comment: $\delta \mathrm{C}^{13}=+5.7 \%$. The fractionation during combustion was slight in both runs and cannot have affected the radiocarbon age.

\section{U-108. Murchisonf jorden $8 \mathrm{~A}$ oo}

Inorganic fraction of the whalebone used for sample U-109 and U-110. Comment: diluted. $\delta \mathrm{C}^{13}=+11.8 \%$.

U-111. Murchisonf jorden 9 $6740 \pm 110$

Wood from between Oddneset and Billingen, Murchisonfjorden $\left(80^{\circ} 2^{\prime}\right.$ $\mathrm{N}$ Lat, $18^{\circ} 20^{\prime} \mathrm{E}$ Long), Spitsbergen; ca. $8 \mathrm{~m}$ altitude; $15 \mathrm{~m}$ from the sea. Sample from exposed part of log partly buried in pebbles and sand of a raised beach. This level is the upper pumice level. Coll. 1958. $\delta \mathrm{C}^{13}=+0.6 \%$.

\section{U-120. Lady Franklinf jorden 35b}

$9540 \pm 130$

Shells (mostly Saxicava arctica) from Tollénbukta, Lady Franklinfjorden $\left(80^{\circ} 8^{\prime} \mathrm{N}\right.$ Lat, $19^{\circ} 0^{\prime} \mathrm{E}$ Long), Spitsbergen; $8.5 \mathrm{~m}$ altitude; $50 \mathrm{~m}$ from the sea. Sample found in till. This level is the upper pumice level. Coll. 1958. Comment: inner $45 \%$ was used. $\delta \mathrm{C}^{13}=+24.4 \%$.

U-119. Lady Franklinfjorden 35a

$9100 \pm 180$

Shell layer surrounding the part used for sample U-120. Comment: the layer corresponds to $20 \%$ of the shells; $35 \%$ was removed by washing. $\delta \mathrm{C}^{13}=$ $+23.0 \%$.

\section{U-116. Murchisonf jorden 24}

$6650 \pm 110$

Wood from Austre Russøya, Murchisonfjorden $\left(79^{\circ} 59^{\prime} \mathrm{N}\right.$ Lat, $18^{\circ} 22^{\prime}$ E Long), Spitsbergen; $9.0 \mathrm{~m}$ altitude; $100 \mathrm{~m}$ from the sea. Sample from exposed part of a log partly buried in pebbles, sand, and dolomite fragments of a raised beach. This level is the upper pumice level. Coll. 1958. $\delta \mathrm{C}^{13}=+1.7 \%$.

\section{U-173. Langgrunnodden 43b}

$9070 \pm 190$

Mytilus edulis from Langgrunnodden $\left(80^{\circ} 10^{\prime} \mathrm{N}\right.$ Lat, $17^{\circ} 40^{\prime} \mathrm{E}$ Long $)$, Spitsbergen; ca. $9 \mathrm{~m}$ altitude; ca. $100 \mathrm{~m}$ from the sea. Sample collected on surface and in till. This level is above the upper pumice level. Coll. 1958. Comment: inner $13 \%$ was used. Diluted. $\delta \mathrm{C}^{13}=+22.7 \%$.

\section{U-174. Langgrunnodden 43 a}

$8400 \pm 190$

Shell layer surrounding the part used for sample U-173. Comment: the layer corresponds to $14 \%$ of the shells; $73 \%$ was removed by washing. Diluted. $\delta \mathrm{C}^{13}=+23.0 \%$.

\section{U-162. Murchisonf jorden 8 B b}

$9730 \pm 130$

Shells (mostly Saxicava arctica) from E side of Vestre Tvillingneset, Murchisonfjorden $\left(80^{\circ} 3^{\prime} \mathrm{N}\right.$ Lat, $18^{\circ} 9^{\prime} \mathrm{E}$ Long), Spitsbergen; 9 m altitude; $75 \mathrm{~m}$ from the sea. Collected in patterned ground formed in till over dolomite bedrock. This level is slightly above upper pumice level. Coll. 1958. Comment: inner $30 \%$ was used. $\delta \mathrm{C}^{13}=+23.1 \%$.

U-161. Murchisonf jorden $8 \mathrm{~B}$ a

$9380 \pm 150$

Shell layer surrounding the part used for sample U-162. Comment: the layer corresponds to $25 \%$ of the shells; $45 \%$ was removed by washing. $\delta \mathrm{C}^{13}=$ $+22.8 \%$. 
U-175. Murchisonf jorden 3

$7500 \pm 150$

Wood from W side of Kvalrosshalvøya, Murchisonfjorden $\left(79^{\circ} 59^{\prime} \mathrm{N}\right.$ Lat, $18^{\circ} 35^{\prime} \mathrm{E}$ Long), Spitsbergen; $11.3 \mathrm{~m}$ altitude; $55 \mathrm{~m}$ from the sea. Sample from the exposed end of a log partly buried in pebbles and sand of a raised beach, at back side of cut terrace. This level is above upper pumice level (here at $9.8 \mathrm{~m}$ ). Coll. 1957. $\delta \mathrm{C}^{13}=-1.4 \%$ o

\section{U-114. Lady Franklinf jorden 13 o I}

$8270 \pm 170$

Organic fraction of whalebone from $\mathrm{NE}$ side of Teodolitkollen, facing Søre Franklinbreen, Lady Franklinfjorden $\left(80^{\circ} 5^{\prime} \mathrm{N}\right.$ Lat, $19^{\circ} 15^{\prime} \mathrm{E}$ Long $)$, Spitsbergen; $17.6 \mathrm{~m}$ altitude; $300 \mathrm{~m}$ from the sea. The bone was partly buried in pebbles and sand of a raised beach. This level is above upper pumice level. Coll. 1958. Comment: this fraction corresponds to the first portion of $\mathrm{CO}_{2}$. See U-109 (this date list) for greater acceptability of organic fractions of whalebone. $\delta \mathrm{C}^{13}=+6.3 \%$.

\section{U-115. Lady Franklinf jorden 13 o II $\quad 8530 \pm 180$}

Organic fraction of the whalebone used for sample U-114 and U-113, obtained at the end of combustion. Comment: $\delta \mathrm{C}^{13}=+5.4 \%$ (no fractionation during combustion).

U-113. Lady Franklinf jorden 13 oo $6560 \pm 170$

Inorganic fraction of the whalebone used for sample U-114 and U-115. Comment: diluted. $\delta \mathrm{C}^{13}=+9.8 \%$.

U-179. Murchisonf jorden $45 b$

$9660 \pm 130$

Saxicava arctica and probably Mya truncata from Kvalrosshalvøya, Murchisonfjorden $\left(79^{\circ} 59^{\prime} \mathrm{N}\right.$ Lat, $18^{\circ} 35^{\prime} \mathrm{E}$ Long), Spitsbergen; ca. $22 \mathrm{~m}$ altitude; ca. $100 \mathrm{~m}$ from the sea. Shells coll. from sorted circles of boulders eroded from near the top of a hill. Coll. 1958. Comment: inner $17 \%$ of the shells was used. $\delta \mathrm{C}^{13}=+25.2 \%$.

U-180. Murchisonf jorden $\mathbf{4 5} a_{1}$

$9640 \pm 180$

Shell layer surrounding the part used for sample U-179. Comment: layer corresponds to $12 \%$ of the shells; $71 \%$ was removed by washing. $\delta \mathrm{C}^{13}=$ $+23.1 \%$.

U-95. Murchisonf jorden $40 \mathrm{~b}$

$9830 \pm 130$

Mya truncata from valley E of Weaselbukta, Murchisonfjorden $\left(80^{\circ} \mathrm{l}^{\prime}\right.$ $\mathrm{N}$ Lat, $18^{\circ} 55^{\prime} \mathrm{E}$ Long), Spitsbergen; $31 \mathrm{~m}$ altitude; $500 \mathrm{~m}$ from the sea. Shells coll. in a shingle beach formed on till. Coll. 1958. Comment: inner 35\% of the shells was used. $\delta \mathrm{C}^{13}=+23.4 \%$.

U-94. Murchisonf jorden 40a

$9750 \pm 190$

Shell layer surrounding the part used for sample U.95. Comment: layer corresponds to $40 \%$ of the shells; $25 \%$ was removed by washing. $\delta \mathrm{C}^{13}=$ $+24.2 \%$.

\section{U.89. Lady Franklinf jorden 34b}

$39,700+1500$

Shells (mostly Saxicava arctica) from the inland of Sevrinberget, Lady Franklinfjorden ( $80^{\circ} 5^{\prime} \mathrm{N}$ Lat, $19^{\circ} 7^{\prime} \mathrm{E}$ Long), Spitsbergen; $44 \mathrm{~m}$ altitude; $1 \mathrm{~km}$ from the sea. Shells coll. from sorted stone circles in till overlying shale. 
Comment: inner $68 \%$ was used. $\delta \mathrm{C}^{13}=+24.0 \%$.

U-88. Lady Franklinf jorden 34a

$$
\mathbf{2 7 , 5 0 0}+\mathbf{9 0 0}
$$

Shell layer surrounding the part used for sample U-89. Comment: layer corresponds to $24 \%$ of the shells; $8 \%$ was removed by washing. $\delta \mathrm{C}^{13}=$ $+23.1 \%$.

U-166. Murchisonf jorden $47 b$

$9640 \pm 120$

Saxicava arctica and Mya truncata from Weaselbukta, Murchisonfjorden $\left(80^{\circ} \mathrm{l}^{\prime} \mathrm{N}\right.$ Lat, $18^{\circ} 53^{\prime} \mathrm{E}$ Long), Spitsbergen; ca. $44 \mathrm{~m}$ altitude; ca. $200 \mathrm{~m}$ from the sea. Coll. 1958 by Valter Schytt, Geografiska Institutet, Stockholms Högskola, Stockholm. Comment: inner $10 \%$ was used. $\delta \mathrm{C}^{13}=+23.9 \%$.

U-165. Weaselbukta 47a

$10,040 \pm 200$

Shell layer surrounding the part used for sample U-166. Comment: layer corresponds to $15 \%$ of the shells; $75 \%$ was removed by washing. $\delta \mathrm{C}^{13}=$ $+25.0 \%$.

\section{U-118. Lady Franklinf jorden 30b}

$$
37,000+3000
$$

Shells from the top of Teodolitkollen facing Søre Franklinbreen $\left(80^{\circ} 5^{\prime}\right.$ $\mathrm{N}$ Lat, $19^{\circ} 20^{\prime} \mathrm{E}$ Long) ; $52 \mathrm{~m}$ altitude; $400 \mathrm{~m}$ from the sea. Coll. from sorted stone circles in till overlying shale, very nearly at the upper limit of shells. Coll. 1958. Comment: some shells from this place dated earlier: (Olsson, 1959), U.71, 36,000 +2000 . Inner $40 \%$ was used. $\delta \mathrm{C}^{13}=+23.6 \%$.

\section{U-117. Lady Franklinf jorden 30a}

$$
29,800 \pm 1000
$$

Shell layer surrounding the part used for sample U.118. Comment: layer corresponds to $20 \%$ of the shells; $40 \%$ was removed by washing. $\delta \mathrm{C}^{13}=$ $+23.9 \%$.

\section{U-172. Lady Franklinf jorden $30 b^{\prime}$}

$$
35,000+2400
$$

Shells from the top of Teodolitkollen facing Søre Franklinbreen $\left(80^{\circ} 5^{\prime}\right.$ $\mathrm{N}$ Lat, $19^{\circ} 20^{\prime} \mathrm{E}$ Long) ; $52 \mathrm{~m}$ altitude. These shells are from the same place and collected together with the shells used for U.71, U-118, and U.117. Comment: inner $22 \%$ was used. $\delta \mathrm{C}^{13}=+23.1 \%$.

\section{U-171. Lady Franklinf jorden $30 a^{\prime}$}

$$
32,500+2000
$$

Shell layer surrounding the part used for sample U-172. Comment: diluted. Layer corresponds to $8 \%$ of the shells. $\delta \mathrm{C}^{13}=+23.3 \%$.

$$
\text { U-178. Lady Franklinf jorden } 30 a^{\prime}{ }_{2} \quad \mathbf{3 5 , 2 0 0} \begin{array}{r}
+\mathbf{2 4 0 0} \\
-1900
\end{array}
$$

Shell layer surrounding the part used for sample U-171 and U-172. Comment: layer corresponds to $10 \%$ of the shells; $60 \%$ was removed by washing. $\delta \mathrm{C}^{13}=+24.1 \%$.

U-181. Lady Franklinf jorden $33 \mathrm{~b}$

$$
40,300+4100
$$

Shells (mostly Saxicava arctica) from the tundra $\mathrm{S}$ of Sevrinberget $\left(80^{\circ}\right.$ 
$4^{\prime} \mathrm{N}$ Lat, $19^{\circ} 10^{\prime} \mathrm{E}$ Long), Lady Franklinfjorden, Spitsbergen; $57 \mathrm{~m}$ altitude; $3 \mathrm{~km}$ from the sea. Coll. from till overlying shale, these shells are the highest found in this area and are probably near the upper marine limit. Coll. 1958. Comment: some shells from this place were dated earlier: (Olsson, 1959), U.72, 38,500 $\begin{array}{r}+3500 \\ -2500\end{array}$. Inner $14 \%$ was used. $\delta \mathrm{C}^{13}=+23.1 \%$.

\section{U-182. Lady Franklinf jorden $33 a_{1} \quad 33,700+2800$}

Shell layer surrounding the part used for U-181. Comment: layer corresponds to $13 \%$ of the shells. $\delta \mathrm{C}^{13}=+25.3 \%$.

\section{U-183. Lady Franklinf jorden $33 \mathbf{a}_{2}$ \\ $\mathbf{3 4 , 5 0 0}+\mathbf{2 9 0 0}$}

Shell layer surrounding the part used for sample U-181 and U-182. Comment: layer corresponds to $12 \%$ of the shells; $61 \%$ was removed by washing. $\delta \mathrm{C}^{13}=+23.2 \%$.

\section{U-87. Lady Franklinf jorden 39b}

Shells (most Saxicava arctica, a few Mya truncata) from $1 \mathrm{~km} \mathrm{NW}$ of Sørberget on the S side of Lady Franklinfjorden $\left(80^{\circ} 8^{\prime} \mathrm{N}\right.$ Lat, $18^{\circ} 58^{\prime} \mathrm{E}$ Long), Spitsbergen; $77 \mathrm{~m}$ altitude; $5 \mathrm{~km}$ from the sea. Coll. from calcareous till underlying beaches. Coll. 1958. Comment: inner $59 \%$ was used. $2 \sigma$ is used. $\delta \mathrm{C}^{13}=+20.5 \%$.

\section{U-86. Lady Franklinf jorden 39a \\ $\mathbf{3 3 , 0 0 0}+\mathbf{2 0 0 0}$}

Shell layer surrounding the part used for sample U-87. Comment: layer corresponds to $39 \%$ of the shells; $2 \%$ was removed by washing. $\delta \mathrm{C}^{13}=$ $+20.3 \%$.

U-92. Murchisonf jorden $\mathrm{H} / 131$ to $135 \quad 9900 \pm 550$

Limnic peat and algal mud from Kristalvatnet $\left(79^{\circ} 58^{\prime} \mathrm{N}\right.$ Lat, $18^{\circ} 40^{\prime}$ $\mathrm{E}$ Long) on the $\mathrm{S}$ side of Murchisonfjorden, Spitsbergen; $62 \mathrm{~m}$ altitude; depth of water $19 \mathrm{~m}$. Sample taken 131 to $135 \mathrm{~cm}$ below top of a core, $141 \mathrm{~cm}$ long, with till below the sample. Coll. 1958 and subm. by Anders Häggblom, Uppsala Universitets Kvartärgeologiska Institution. Comment: diluted, $\delta \mathrm{C}^{13}=-8.9 \%$.

U-93. Murchisonf jorden D/1 60 to 67

$5160 \pm 400$

Limnic peat in clayey gyttja from Trippvatnet $\left(80^{\circ} 1^{\prime} \mathrm{N}\right.$ Lat, $18^{\circ} 47^{\prime} \mathrm{E}$ Long) on the $\mathrm{S}$ side of Norvika, Murchisonfjorden, Spitsbergen; altitude $5.2 \mathrm{~m}$. Sample taken 60 to $67 \mathrm{~cm}$ below top of a core $127.5 \mathrm{~cm}$ long. According to preliminary analysis of the diatoms, between 93.5 and $127.5 \mathrm{~cm}$ there are marine layers. Coll. 1958 and subm. by Anders Häggblom, Uppsala Universitets Kvartärgeologiska Institution. Comment: diluted, $\delta \mathrm{C}^{13}=-0.7 \%$.

\section{Norwegian local-glaciation series}

$$
\text { D. Norway }
$$

Peat from different bogs. A continuation of the Vesterålen series (Olsson, 1959), taken to determine the variations in extent of the recent local glaciation in the Scandinavian mountains and to study the question of the existence of ice-free refuges in Scandinaria (Holtedahl and Rosenqvist, 1958; Nann- 
feldt, 1958; Lindroth, 1958; Bergström, 1959; Hoppe, 1959; Erdtman, 1959; Lundholm, 1959). Coll. 1958 and subm. by Erik Bergström, Geografiska Institutet, Stockholms Högskola, Stockholm.

\section{U-97. Fongen I}

$7990 \pm 120$

Peat from Fongen $\left(63^{\circ} 10^{\prime} \mathrm{N}\right.$ Lat, $11^{\circ} 40^{\prime} \mathrm{E}$ Long), Sör-Tröndelag, Norway, from $270 \mathrm{~cm}$ below the surface. Above and below the sample there are layers of fine clayey silt underlying a peat layer $210 \mathrm{~cm}$ thick. There is another thin peat layer in the silt above the sample. $\delta \mathrm{C}^{13}=-2.8 \%$.

\section{U-98. Heimerdalsvand II}

$5860 \pm 100$

Peat (alkali-insoluble fraction) from Heimerdalsvand $\left(68^{\circ} 18^{\prime} \mathrm{N}\right.$ Lat, $13^{\circ}$ $38^{\prime}$ E Long), Lofoten, Norway, from $120 \mathrm{~cm}$ below the surface. The youngest Tapes-transgression layer with boulders and gravel is situated between this sample and $\mathrm{U}-99.8 \mathrm{C}^{13}=-3.4 \%$.

\section{U-99. Heimerdalsvand III}

$3440 \pm 90$

Peat (alkali-insoluble fraction) from Heimerdalsvand $\left(68^{\circ} 18^{\prime} \mathrm{N}\right.$ Lat, $13^{\circ} 38^{\prime} \mathrm{E}$ Long), Lofoten, Norway. Sample taken in a peat bog $50 \mathrm{~cm}$ below the surface above the Tapes layer. $\delta \mathrm{C}^{13}=-3.2 \%$.

U-160. Heimerdalsvand II $h$

$5610 \pm 150$

Humus (alkali-soluble fraction) from sample U.98. This sample was measured to check if sample U-98 was contaminated by humus from the peat corresponding to sample U.99. $\delta \mathrm{C}^{13}=-4.5 \%$.

U-100. Aaknes IV

$4600 \pm 90$

Peat from Aaknes ( $68^{\circ} 59^{\prime} \mathrm{N}$ Lat, $15^{\circ} 27^{\prime} \mathrm{E}$ Long), Andøya, Vesterålen, Nordland, Norway, from $300 \mathrm{~cm}$ below the water surface at the bottom of the peat of a bog, which is dammed by a local lateral moraine drum. $\delta \mathrm{C}^{13}=$ $-3.7 \%$.

U-101. Djupvika V

$7500 \pm 120$

Peat from Djupvika $\left(69^{\circ} 45^{\prime} \mathrm{N}\right.$ Lat, $20^{\circ} 30^{\prime} \mathrm{E}$ Long), Troms, Norway, from bottom of the peat layer, $300 \mathrm{~cm}$ thick, immediately above a layer of till. $\delta \mathrm{C}^{13}=-3.9 \%$.

U-102. Bleik VI

$4240 \pm 90$

Peat from Bleik $\left(69^{\circ} 16^{\prime} \mathrm{N}\right.$ Lat, $15^{\circ} 55^{\prime} \mathrm{E}$ Long), Andøya, Vesterålen, Nordland, Norway, from bottom of the peat layer, $160 \mathrm{~cm}$ thick, immediately overlying a layer of till. $\delta \mathrm{C}^{13}=-3.7 \%$.

U-103. Bleik VII

$5830 \pm 100$

Peat from Bleik $\left(69^{\circ} 16^{\prime} \mathrm{N}\right.$ Lat, $15^{\circ} 55^{\prime} \mathrm{E}$ Long), Andøya, Vesterålen, Norway, from $330 \mathrm{~cm}$ below the water surface at the bottom of bog peat immediately overlying a layer of boulders. $\delta \mathrm{C}^{13}=-4.8 \%$.

U-104. Nakkevann VIII

$9930+150$

Peat from Nakkevann $\left(69^{\circ} 33^{\prime} \mathrm{N}\right.$ Lat, $19^{\circ} 33^{\prime}$ E Long), Troms, Norway, from bottom of the peat layer, $200 \mathrm{~cm}$ thick, immediately overlying a layer of boulders. $\delta \mathrm{C}^{13}=-3.4 \%$.

U-105. Reknes IX

$8370 \pm 130$

Peat from Reknes $\left(68^{\circ} 18^{\prime} \mathrm{N}\right.$ Lat, $15^{\circ} 50^{\prime} \mathrm{E}$ Long), Nordland, Norway, 
from bottom of the peat layer, $200 \mathrm{~cm}$ thick, immediately overlying a layer of till. $\delta \mathrm{C}^{13}=-3.5 \%$.

U-106. Sörlenangen $X$

$3550 \pm 90$

Peat from Sörlenangen ( $69^{\circ} 45^{\prime}$ N Lat, $19^{\circ} 57^{\prime}$ E Long), Troms, Norway, from bottom of the peat layer, $100 \mathrm{~cm}$ thick, immediately overlying a layer of till. $\delta \mathrm{C}^{13}=-3.2 \%$.

U-79. Elvegård

$6110 \pm 110$

Wood, probably Alnus, from Elvegård ( $68^{\circ} 14^{\prime} \mathrm{N}$ Lat, $17^{\circ} 52^{\prime}$ E Long), Skjomen, Nordland, Norway. The log, length ca. $1.5 \mathrm{~m}$ and diam. 5 to $10 \mathrm{~cm}$, was found in a delta sediment, raised in postglacial time so that its surface is $32 \mathrm{~m}$ above the present high-tide level. The log was embedded in a sand layer $29 \mathrm{~m}$ below that surface. Coll. 1958 and subm. by Ragnar Dahl, Uppsala Universitets Geografiska Institution. $\delta \mathrm{C}^{13}=-0.4 \%$.

\section{U-91. Lassehaga}

\section{E. Sweden}

Ericaceous peat from Lassehaga $\left(58^{\circ} 19.5^{\prime} \mathrm{N}\right.$ Lat, $11^{\circ} 31^{\prime} \mathrm{E}$ Long) Lyse parish, Bohuslän, Sweden, from 20 to $22 \mathrm{~cm}$ below the surface and near the bottom of the peat layer. Coll. 1957 and subm. by Magnus Fries, Uppsala Universitets Växtbiologiska Institution. Comment: the formation of the peat was supposed to have started when the climate turned wetter and cooler in 500 B.C. (or A.D. 400). Pollen analysis (Fries, 1960) does not give any clue to the age of the peat. From the unexpectedly young $\mathrm{C}^{14}$ date it must be considered that the formation started in connection with deforestation. $\delta \mathrm{C}^{13}=$ $-3.6 \%$.

U-78. Granvåg

$1435 \pm 80$

Wood, probably Populus, from Granvåg at the river Ångermanälven $\left(63^{\circ}\right.$ $11^{\prime} \mathrm{N}$ Lat, $18^{\circ} 53.5^{\prime} \mathrm{E}$ Long), Ångermanland, Sweden. The log, length ca. $11 \mathrm{~m}$ and largest diam. ca. $30 \mathrm{~cm}$, was lying in sand and gravel $4.6 \mathrm{~m}$ below the surface, which here is $15 \mathrm{~m}$ above sealevel. The sand layer overlies an esker. Inner tree rings were used. Age of the tree was 60 yr. Coll. 1958 and subm. by Lennart Arnborg, Uppsala Universitets Geografiska Institution. $\delta \mathrm{C}^{13}=-2.4 \%$.

\section{U-135. Krokom}

$1610 \pm 90$

Charcoal, Pinus, from Krokom (63 $13^{\circ} 19^{\prime} \mathrm{N}$ Lat, $14^{\circ} 30.5^{\prime}$ E Long), Jämtland, Sweden. Coll. in a gravel layer below the till. The location was described by Frödin (1954), who discussed the last stages of the glacial history of Jämtland. Coll. 1958 by Sven Svensson. Uppsala Universitets Geografiska Institution; subm. by Filip Hjulström, Uppsala Universitets Geografiska Institution. $\delta \mathrm{C}^{13}=-1.1 \%$.

U-136. Krokom, diluted

$1720 \pm 160$

Charcoal from the same origin as U-135. Comment: new treatment, diluted. $\delta \mathrm{C}^{13}=-0.6 \%$.

\section{Weber Lake series}

$F$. North America
Samples of Special Palynologic Interest

Limnic gyttja, noncalcareous, from one core from Weber Lake $\left(47^{\circ} 28^{\prime}\right.$ 
$\mathrm{N}$ Lat, $91^{\circ} 35.5^{\prime} \mathrm{W}$ Long), Lake County, Minnesota. The pollen analysis (Fries) is not yet finished. Coll. 1959 and subm. by Magnus Fries, Uppsala Universitets Växtbiologiska Institution. One sample of the same core (710 to $750 \mathrm{~cm}$ ) has been dated by the U. S. Geological Survey Laboratory (Rubin and Alexander, 1960): W-873, 10,550 \pm 330 .

U-163. Weber 440 to 447

$7300 \pm 140$

Gyttja from 440 to $447 \mathrm{~cm}$ below the reference level (ice). The gyttja layer is especially rich in plant fragments, perhaps indicating a lower water level (and maybe a drier climate) than later. Comment: diluted. $\delta \mathrm{C}^{13}=$ $+7.7 \%$.

U-164. Weber 620 to 633

$9150 \pm 130$

Gyttja from 620 to $633 \mathrm{~cm}$ below the reference level. From a part of a fine-detrital gyttja layer where Picea pollen decreases and Pinus pollen increases, forming an important pollen-analytic index level. $\delta \mathrm{C}^{13}=+3.9 \%$.

\section{ARCHAEOLOGIC SAMPIES}

\section{Belen series}

\section{A. Argentina}

Charcoal from Belen. Coll. 1952 and subm. by Alberto Rex González, Instituto de Antropología, Universidad de Córdoba, Argentina.

U-153. Belen I

$795 \pm 80$

Prosopis nigra from Corral de Ramas $\left(27^{\circ} 35^{\prime} 18^{\prime \prime} \mathrm{S}\right.$ Lat, $67^{\circ} 38^{\prime} 25^{\prime \prime}$ W Long), Condorhuasi, Dto. de Belen, Catamarca, Argentina. Sample taken from a $\log$ in a post hole belonging to a pit-house, Belen culture, supposed to be about $700 \mathrm{yr}$ old. The pit-house is described by González (1954) $. \delta \mathrm{C}^{13}=$ $-0.6 \%$.

\section{U-154. Belen II}

$580 \pm 80$

Algarrobo trees and jarilla (Prosopis, Larrea, etc.) from a hearth at

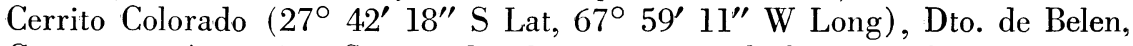
Catamarca, Argentina. Supposed to be ca. $600 \mathrm{yr}$ old because of its proximity in time to the Inca conquest of northwest Argentina. $\delta \mathrm{C}^{13}=-0.8 \%$.

\section{U-155. Aguada}

$1180 \pm 85$

Prosopis alba and Larrea divaricata from La Cienaga $\left(27^{\circ} 10^{\prime} 22^{\prime \prime} \mathrm{S}\right.$ Lat, $67^{\circ} 5^{\prime} 33^{\prime \prime}$ W Long), Dto. de Belen, Catamarca, Argentina. Taken from an earth-packed floor of a dwelling place of La Aguada type. The site is described by González (1955). $\delta \mathrm{C}^{13}=-0.6 \%$. Charcoal from Site 10, Hualfin Valley was dated by Broecker and Kulp (1957): L-307, $1130 \pm 90$.

\section{U-156. Pachacamac}

\section{B. Peru}

Cloth from Pachacamac ( $12^{\circ} 13^{\prime} \mathrm{S}$ Lat, $76^{\circ} 53^{\prime} \mathrm{W}$ Long), Lima, Peru, found in surface layer of desert sand near the temple. It belonged, according to an Indian guide, to a mummy, dug out a few years ago. The locality was described by Max Uhle (1903). Coll. 1958 and subm. by Tor Ragnar Gerholm, Uppsala Universitets Fysiska Institution. $\delta \mathrm{C}^{13}=-0.1 \%$. 
U.134. Buchberg

C. Austria

$3040 \pm 90$

Coniferous wood from Kupferbergbau ( $47^{\circ} 23^{\prime} \mathrm{N}$ Lat, $13^{\circ} 8^{\prime} \mathrm{E}$ Long), Buchberg near Bischofshofen. The log belonged to an old copper mine. Coll. by W. Lob, Kupferbergbau Mitterberg Ges. m.b.H. Mühlbach am Hochkönig, Salzburg, Austria; subm. by Otto Barth, Sweden. $\delta \mathrm{C}^{13}=-0.6 \%$.

\section{Simris series}

D. Sweden

Charcoal and resin from the grave field at Simris $\left(55^{\circ} 32^{\prime} \mathrm{N} \mathrm{Lat}, 13^{\circ} 19^{\prime}\right.$ E Long), Simris parish, Skåne, Sweden. Described by Stjernquist (in preparation). Coll. and subm. by Berta Stjernquist, Lunds Universitets Historiska Museum, Lund. One sample from the same grave field as the samples in this series was dated by Olsson (1959) : U-49, $2650 \pm 80$. The Bronze Age periods used below are classified according to Montelius' system.

U-144. Simris no. 2, 71

$2690 \pm 80$

Resin from grave 71 , used to seal an earthen burial urn, assumed to belong to the 5th period of the Bronze Age because of a bar-button of bronze which was found in the urn. Coll. 1951. $\delta \mathrm{C}^{13}=-4.1 \%$.

U-138. Simris no. 2, 75

$2290 \pm 160$

Charcoal from grave 75 , found in a pit together with burned bone; depth about 0.2 to $0.4 \mathrm{~m}$ below the present surface. Sample is assumed to belong to the late Bronze Age or the early Iron Age because of some potsherds found in the pit. Coll. 1951. Comment: diluted. $\delta \mathrm{C}^{13}=-0.3 \%$.

U-145. Simris no. 2, 79A $\quad 2560 \pm 90$

Resin from grave 79A, used to seal the lid of an urn, assumed to belong to the 5th period of the Bronze Age because of a bronze razor found in the urn. Coll. 1951. $\delta \mathrm{C}^{13}=-5.5 \%$.

U-84. Simris no. 2,94

$2690 \pm 90$

Resin from grave 94, used to seal the lid of an urn, assumed to belong to the 5th period of the Bronze Age because of a bronze razor found in the urn. Coll. 1951. $\delta \mathrm{C}^{13}=-1.9 \%$.

U-146. Simris no. $2,48 \quad 2510 \pm 80$

Resin from grave 48 , used to seal the lid of an urn, whose shape indicates the 5 th or the 6th period of the Bronze Age. Coll. 1950. $\delta \mathrm{C}^{13}=-5.3 \%$.

U-137. Simris no. 2,68

$\mathbf{2 7 3 0} \pm \mathbf{7 0}$

Charcoal from grave 68 , found in a pit ca. $0.5 \mathrm{~m}$ below the surface together with burned bone. No artifacts were found. Coll. 1951. $\delta \mathrm{C}^{13}=-0.8 \%$.

U-167. Simris no. 2, 69

$2015 \pm 80$

Charcoal from grave 69 , found in a pit ca. $0.3 \mathrm{~m}$ below the surface together with soot, burned bone, and a few fire-scarred stones. No artifacts were found. Coll. 1951. $\delta \mathrm{C}^{13}=-0.1 \%$.

U-147. Simris no. 2,57

$2640 \pm 110$

Charcoal from grave 57 , found in a pit ca. $0.6 \mathrm{~m}$ below the surface together with burned bone. The position of the grave in the grave field, as well 
as some pieces of iron, indicate the beginning of the Iron Age. Coll. 1951. Comment: diluted. $\delta \mathrm{C}^{13}=-5.3 \%$.

U-139. Svarte (Luhm 20153:55:E)

$\mathbf{2 0 5 0} \pm \mathbf{8 0}$

Charcoal from a pit at Svarte $\left(55^{\circ} 25.5^{\prime} \mathrm{N}\right.$ Lat, $13^{\circ} 43.5^{\prime} \mathrm{E}$ Long $)$, Balkåkra parish, Skåne, Sweden. No artifacts were found, but in the neighborhood there are graves from the late Bronze Age. Described by Hansen (1923). Coll. about 1920 by Folke Hansen, Lunds Universitets Historiska Museum, Lund; subm. by Berta Stjernquist, Lunds Universitets Historiska Museum, Lund. $\delta \mathrm{C}^{13}=-1.9 \%$.

\section{Dragby series}

Resin and charcoal from Dragby $1^{1}\left(59^{\circ} 59^{\prime} \mathrm{N}\right.$ Lat, $17^{\circ} 35^{\prime} \mathrm{E}$ Long), Skuttunge parish, Uppland, Sweden. The results of the excavation are discussed from different points of view by Stenberger (1960), Maj-Britt and Sten Florin (1960) and Olsson (1960). Subm. by Mårten Stenberger, Uppsala Universitets Institution för Nordisk och Jämförande Fornkunskap.

U-96. Dragby $1^{1}: 97: 2 \quad 2130 \pm 100$

Resin from grave 97, found together with burned bone in a pit under stone paving. Coll. 1958 by Ulf Erik Hagberg, Uppsala Universitets Institution för Nordisk och Jämförande Fornkunskap. $\delta \mathrm{C}^{13}=-3.4 \%$.

U-80. Dragby $1^{1}: 105: 1$

$\mathbf{2 5 0 0} \pm \mathbf{9 0}$

Charcoal from grave 105, found in a layer, $5 \mathrm{~cm}$ thick, ca. $0.35 \mathrm{~m}$ below the surface under stone paving. Coll. 1958 by Ulf Erik Hagberg, Uppsala Universitets Institution för Nordisk och Jämförande Fornkunskap. $\delta \mathrm{C}^{13}=$ $-1.4 \%$.

U-82. Dragby $1^{1}: 137: 1$

$2490 \pm 90$

Resin from grave 137, found together with burned bone on sandy soil ca. $0.35 \mathrm{~m}$ below the surface under stone paving. Coll. 1958 by Ulf Erik Hagberg, Uppsala Universitets Institution för Nordisk och Jämförande Fornkunskap. $\delta \mathrm{C}^{13}=-2.4 \%$.

U-81. Dragby $1^{1}: 148: 10$

$3120 \pm 90$

Charcoal from grave 148, found ca. $0.5 \mathrm{~m}$ below the surface in a layer with small stones, ca. $0.1 \mathrm{~m}$ above sterile gravel. Coll. 1958 by Lars Gezelius, Uppsala Universitets Institution för Nordisk och Jämförande Fornkunskap. $\delta \mathrm{C}^{13}=-0.5 \%$.

U-83. Dragby $1^{1}: 148: 11$

$2625 \pm 90$

Resin from grave 148, found together with burned bone ca. $1 \mathrm{~m}$ below the surface in a stone cyst. Coll. 1958 by Lars Gezelius, Uppsala Universitets Institution för Nordisk och Jämförande Fornkunskap. $\delta \mathrm{C}^{13}=-1.8 \%$.

U-148. Dragby $I^{1}: 151$

$2620 \pm 90$

Charcoal from grave 15l, found in a wide dark layer about 0.4 to $0.5 \mathrm{~m}$ beneath the surface. The layer may belong to an old peat surface; it was covered by a stone paving, broken in the center, where bronze artifacts and burned bone were found. Coll. 1959 by Bia Wallace and Inger Zetterberg, Uppsala Universitets Institution för Nordisk och Jämförande Fornkunskap. $\delta \mathrm{C}^{13}=+0.9^{\%} \%$. 
U-149. Dragby $1^{1}: 88: k$

$1340 \pm 90$

Charcoal from grave 88 , found ca. $0.25 \mathrm{~m}$ below the surface in a small stone layer in black burned soil at the NE border of the cairn. Coll. 1959 by Lennart Lundborg and Inger Zetterberg, Uppsala Universitets Institution för Nordisk och Jämförande Fornkunskap. $\delta \mathrm{C}^{13}=-1.2 \%$.

U-150. Dragby $I^{1}: 88: I, k$ II

$1190 \pm 80$

Charcoal from a secondary burial in the middle of grave 88 , found on a stone paving ca. $0.4 \mathrm{~m}$ below the surface. In this secondary burial burned bone and an iron ring were found. Coll. 1959 by Anders Åman and Inger Zetterberg, Uppsala Universitets Institution för Nordisk och Jämförande Fornkunskap. $\delta \mathrm{C}^{13}=-1.9 \%$.

U-151. Dragby $1^{1}: 88:$ :I h

$$
1940 \pm 80
$$

Resin from a secondary burial in the NW slope of the cairn of grave 88, found ca. $0.4 \mathrm{~m}$ below the surface together with charcoal (sample U-152) and burned bone. Coll. 1959 by Mårten Stenberger, Uppsala Universitets Institution för Nordisk och Jämförande Fornkunskap. $\delta \mathrm{C}^{13}=-3.5 \%$.

U-152. Dragby $1^{1}: 88:$ II $\mathrm{k}$

Charcoal from grave 88, found together with burned bone and with resin (sample U-151). Coll. 1959 by Mårten Stenberger, Uppsala Universitets Institution för Nordisk och Jämförande Fornkunskap. $\delta \mathrm{C}^{13}=-1.4 \%$.

\section{ATOMIC BOMB EFFECT}

The values are related to the Uppsala reference sample corrected only for decay due to age. The results give the excess in percent over the corrected reference sample.

\section{U-74. Typha 58}

$+\mathbf{1 3 . 5} \pm \mathbf{0 . 8 \%}$

Typha latifolia from Ekensberg $\left(59^{\circ} 48.5^{\prime} \mathrm{N}\right.$ Lat, $17^{\circ} 34.5^{\prime} \mathrm{E}$ Long), Uppsala, Sweden. The plant was gathered November 9, 1958 by the author. Comment: $\delta \mathrm{C}^{13}=-2.0 \%$; this value is included in the $\mathrm{C}^{14}$ calculation.

\section{U-157. Typha 59}

$+31.4 \pm 0.8 \%$

Typha latifolia from Ekensberg (59 $48.5^{\prime} \mathrm{N}$ Lat, $17^{\circ} 34.5^{\prime}$ E Long), Uppsala, Sweden. The plant was gathered July 5,1959 by the author. Com. ment: $\delta \mathrm{C}^{13}=-3.2 \%$; this value is included in the $\mathrm{C}^{14}$ calculation.

\section{REFERENCES}

Arnborg, Lennart, 1959, Nedre Āngermanalven. Del. II: Uppsala Geog. Inst. Phys. Geography Pub. 2, $180 \mathrm{p}$.

Bergström, Erik, 1959, Utgjorde Lofoten och Vesterålen ett refugium under sista istiden? Svensk Naturvetenskap, v. 12, p. 116-121 [English summ., p. 122].

Blake, Weston, Jr., 1959, Radiocarbon dating of raised beaches in Nordaustlandet, Spitsbergen: Canad. Oil and Gas Industries, v. 12, p. 51 [abst. of paper presented at 1st Internat. Symposium on Arctic Geology, Calgary, Alberta, Canada, January 1960].

Broecker, in ms, Russian settlement and land rise in Nordaustlandet. ecker, W. S., and Kulp, J. L., 1957, Lamont natural radiocarbon measurements IV Science, v. 126, p. 1324-1334.

Donner, J. J., and West, R. G., 1957, The Quaternary geology of Brageneset, Nordaustlandet, Spitsbergen: Norsk polarinst. skr. 109, 29 p.

Erdtman, Gunnar, 1959, De kvartära klimatcyklerna och övervintringshypotesen: Svensk Naturvetenskap, v. 12, p. 137-137 [English summ., p. 137-138].

Ericson, D. B., Broecker, W. S., Kulp, J. L., and Wollin, Goesta, 1956, Late Pleistocene climates and deep-sea sediments: Science, v. 124, p. 385-389. 
Feyling-Hanssen, R. W., 1955, Stratigraphy of the marine Late-Pleistocene of Billefjorden, Vestspitsbergen: Norsk polarinst. skr. 107, $186 \mathrm{p}$.

Feyling-Hanssen, R. W., and Olsson, Ingrid, in press, The main trend of Late Pleistocene shoreline displacement in Central Spitsbergen: Norsk geog. tidsskr., v. 17.

Florin, Maj-Britt, and Florin, Sten, 1960, Naturhistorisk utveckling vid Dragby under bronsåldern. Från en pabörjad undersökning över områdets kvartärgeologi: Tor, v. 6, p. $87-121$.

Fries, Magnus, 1960, En pollenanalyserad och $\mathrm{C}^{14}$-daterad bohuslänsk ljungtorvsprofil: Svensk bot. tidskr., v. 53 [1959], p. 479-491 [English summ.].

Frödin, Gustav, 1954, De sista skedena av Centraljämtlands glaciala historia: Geografica, v. 24, 251 p. [English summ., p. 230-245].

González, A. R., 1954, La casa-pozo en el N. O. Argentino: Rev. Museo Municipal Ciencias Nat. y Tradicional de Mar del Plata, v. 1, part 2, p. 123-132.

1955, Contextos culturales y cronología relativa en el área Central del N. 0. Argentino: Anales Arqueología y Etnología, v. 11, p. 7-32.

método 1957, Dos feches de la cronología arqueológica argentina obtenidas por el método de radiocarbónno: Inst. Anthropología, Fac. Filosofía, Univ. Nac. del Litoral [Rosario, Argentina], p. 1-19.

in press, Archaeología del Valle del Hualfin.

Hansen, Folke, 1923, De arkeologiska fynden vid Svarte fiskeläge: Fornvännen, v. 18, p. p. 119-164.

Holtedahl, Olaf, and Rosenqvist, I. Th., 1958, "Refugie-problemet" på den skandinaviska halvøy fra geologisk synspunkt: Svensk Naturvetenskap, v. 11 [1957-1958], p. 108118 [English summ., p. 118].

Hoppe, Gunnar, 1959, Några kritiska kommentarer till diskussionen om isfria refugier: Svensk Naturvetenskap, v. 12, p. 123-133 [English summ., p. 134].

Lindroth, C. H., 1958, Istidsövervintrare bland djuren: Svensk Naturvetenskap, v. 11 [1957-1958], p. 134-150 [English summ., p. 150-151].

Lundholm, Bengt, 1959, Övervintring på Nordsjölandet?: Svensk Naturvetenskap, v. 12, p. 138-142 [English summ., p. 142].

Nannfeldt, J. A., 1958, Den skandinaviska fjällfloran och nedisningarna: Svensk Naturvetenskap, v. 11 [1957-1958], p. 119-133 [English summ., p. 133]

Olausson, Eric, 1959, Correlation of cores from the eastern Mediterranean: Internat. Oceanog. Cong., 1959 [preprint edited by Am. Assoc. Advancement Sci., p. 104-105].

Olsson, Ingrid, 1958, A C $\mathrm{C}^{14}$ dating station using the $\mathrm{CO}_{2}$ proportional counting method: Arkiv f. Fysik, v. 13, p. 37-60. 1959, Uppsala natural radiocarbon measurements I: Am. Jour. ScI. Radioc.
Supp., v. 1, p. 87-102. p. $122-124$ beaches.

Rubin, Meyer, and Alexander, Corrine, 1960, U. S. Geological Survey radioc Am. Jour. Sci. Radioc. Supp., v. 2, p. 129-185

Rubin, Meyer, and Suess, H. E., 1955, U. S. Geological Survey radiocarbon dates II: Science, v. 12il, p. 481-488.

Stenberger, Mårten, 1960, Gravfältet vid sockenmötet. Dragby i Skuttunge, orientering och problem: Tor, v. 6 , p. 63-86.

Stjernquist, Bertá, in preparation.

Uhle, Max, 1903, Pachacamac. Report of the Pepper Peruvian Expedition of 1896: Philadelphia, University of Pennsylvania Department of Archaeology. 